\title{
Characteristics of the Consumption Pattern of Household's Small Businesses: (Socio-Economic and Demographic Perspectives)
}

\author{
Sitti Hajerah Hasyim ${ }^{1}$, Muhammad Hasan², Muhammad Imam Ma'ruf ${ }^{3}$ \\ ${ }^{1}$ Universitas Negeri Makassar, Makassar and Indonesia, $\square$ (hajerah_hasyim@unm.ac.id) \\ ${ }^{2}$ Universitas Negeri Makassar, Makassar and Indonesia, $\bowtie$ (m.hasan@unm.ac.id) \\ 32Universitas Negeri Makassar, Makassar and Indonesia, $\bowtie$ (muhammadimammaruf@unm.ac.id)
}

\begin{abstract}
The aim of this study to determine the effect of the socio-economic and demography aspects which includes household heads' education level, business status, and household size to household consumption pattern of small businesses. The study population was the entire household of small businesses in the province of South Sulawesi spread in 24 districts / cities, while the sample in this study were household small businesses located in urban areas with a total sample of 4,520 households. Analysis of data using Regression Logistic Model with a model of the natural logarithm. Simultaneous hypothesis testing using Chi Square Test, whereas partial hypothesis testing using Wald Test. Odd Ratio Test was used to determine the pattern of household consumption of small businesses. The results showed three variables such as household heads' education level, business status and household size significant effect on household consumption patterns of urban small businesses simultaneously. However, only household heads' education level and household size were significant effect on household consumption patterns of small businesses partially.
\end{abstract}

Keywords: consumption patterns, and small businesses

\section{Introduction}

The study of small business in the economy has been long overdue. The results of these studies led to the two perspectives. The first perspective shows there are no role and contribution of the small business sector to the economy (Ayyagari, et al., 2007, 2008; Hurst \& Pungsley 2011, Miliaras, 2012; Gonzales, 2013). The second perspective shows that small business has contributed to the economy (Acs\& Muller, 2008; Klapper, et al., 2009; Stangler and Litan, 2009; Haltiwanger, et al., 2010; Hurst \&Pungsley 2011; Mazzucato, 2013, Hasan, 2014, Hasyim dan Hasan, 2017).

Although small businesses have a strategic role in economic development, this sector still has many problems, mainly because they tend to be subsistence (Khavul et al., 2009; Hasan, 2013; Karedza, et al., 2014; Viswanathan et al., 2014; Carlos, 2017). Financial problems often become one of the major problems and are experienced by the majority of small businesses. In conducting its business, small business operators are not only faced with the problem how to make money, but also the issue of the ability to manage and control the finances. Generally, small businesses do not even think to separate the family finances to corporate finance, it has implications for the difficulties in calculating the expenses and costs (cost). If there is no calculation of the cost, then automatically small businesses do not know how much of the profit generated from the business. The majority of small businesses feel turnover obtained already quite large, but in fact, they did not benefit from his efforts. This is because small businesses have not been able to manage their finances well so that their business despite a longstanding but cannot grow and develop.

Entrepreneurship research has traditionally looked at both individuals and companies paid little attention to the context of the family and household. The view that businesses and households are a 
separate organization challenged. Business development and family as a field of inquiry that separate but related (De Massis et al., 2012, 2013, 2014a, b, 2015, 2016); recognition of the importance of the context of the family household in understanding the creation and growth of enterprises (Welter, 2011); and recent studies have focused on the role of the family household underlying business growth (Alsos et al., 2003, 2006, 2012, 2014a, b; Carter et al., 2015), collectively challenge the notion of separation between business and households.

This research study explores the interaction between household economic behavior of small businesses with its business activities. It shows that the creation and growth of new businesses often rely on business-household relationships, and good business decisions influenced by family circumstances and economic conditions of the family (Welter, 2011). Housekeeping is the smallest social unit where the human and economic resources overlap (Welter, 2011), households can help to explain the social factors underlying economic behavior (Wales et al., 2013). Therefore, in assessing the role of households in the creation and growth of new businesses, the economic behavior of households can be assessed in the perspective of entrepreneurship (Zahra, 2006, 2007; Welter, 2011).

In connection with this, the characteristic of consumption pattern of household is an important aspect to be studied related to the household economic behavior of small businesses with its business activities. The nature and pattern of consumption are reflecting the socio-economic characteristics and demographics of households that will be studied. The determinant of household consumption patterns has become a topic of interest to economists for centuries. Some researchers have made an important contribution to understanding the factors associated with consumer choice. From an empirical perspective, several studies have been conducted to provide insight into the factors that influence household consumption patterns. Gheblawi and Sherif (2007) examined the factors that influence consumption patterns in the UAE. Their findings suggest that household income and size are important factors that influence consumption patterns. Some researchers (Barda\&Sardianou, 2010; Vitaliano, 2010; Jacobson et al., 2010; Garcia \& Grande, 2010; Neulinger\& Simon, 2011; Tekguc, 2012; Francisco et al., 2013; Liu et al., 2013) shows that non-economic factors that include education of household head, household size, and the status of efforts to become more important in determining the pattern of household consumption. Based on empirical studies that have been done, then the special purpose of this study was to analyze the effect of household characteristics of the pattern of household consumption of small business operators. Household small business characteristics include household heads' education levels business status and household size.

\section{Methods}

This research is a survey research using questionnaires in data collection. To get the data in accordance with the study design used types of closed questions (closed-ended question). Type closed question questionnaire aimed to obtain data associated with a variable pattern of consumption, household heads' education level, business status and household size.

Consumption patterns of household small businesses in this study was defined as the proportion of household expenditure allocated small business operators for food and non food needs. For the purposes of the calculation of logistic regression, formed the consumption pattern of household small businesses with reference to: (1) to the allocation pattern of food consumption is less than 50 percent were coded 1, and (2) to the allocation pattern of food consumption by 50 percent to over coded 0 .

The education level of household head in this study was defined as the highest level of education attained by the head of household small businesses. Furthermore, for the purposes of calculating the logistic regression head of household education level above high school to be given the code 1 and for the education level of the household head junior downward coded 0 .

Business status is the status of a small business run by a household consisting of main business and side business. The main business is household businesses as a main source of revenue, while the 
side business is household businesses become an additional source of revenue. Furthermore, side business coded as 0 while the main business was coded 1 .

Household size is the number of family members of household dependent small businesses. Furthermore, for the purposes of calculating the size of the domestic logistic regression with the number of household members 1-4 vote coded 1 and the size of the household by the number of household members 5 upwards coded 0 .

The population of this study was the entire household small businesses in the province of South Sulawesi spread in 24 districts / cities. To get a sample of households small businesses, applied multistage random sampling method. The first phase conducted a census block sample selection of all census block in South Sulawesi, both in urban and rural areas. Selection of census block sample carried probability proportional to size with household size small businesses. From the results of the election census block in South Sulawesi, as many as 602 selected census blocks spread over 24 districts / cities. Of the 602 census block, a total of 452 census blocks are located in urban areas and the remaining 150 census blocks are located in rural areas. The second phase, all of the census blocks were selected next election households small businesses systematically, and selecting the household sample small business is set at 10 households for each census block. In urban areas, the number of households was selected as 4,520 households while in rural areas 1,500 households. The samples in this study are household small businesses located in urban areas with a total sample of 4,520 households.

To determine the functional relationship between the variables of household heads' education level, business status, and household size to consumption pattern of household small businesses use Regression Logistic Model analysis with a model of the natural logarithm. Simultaneous hypothesis Testing using Chi Square test, whereas partial hypothesis testing using the Wald Test. Odd Ratio Test is used to determine the consumption pattern of household small businesses.

\section{Results}

Calculation of logistic regression was performed to household small businesses located in urban areas as many as 4,520 households scattered small business operators in the 24 districts / cities of South Sulawesi Province. The results of Logistic Regression can be seen in Table 1.

Table 1 Logistic Regression Calculation

\begin{tabular}{lccccc}
\hline \multicolumn{1}{c}{ Variables } & Coefficient $(\mathrm{B})$ & Wald & Sig. & Odd Ratio / Exp (B) & df \\
\hline Education $\left(\mathrm{X}_{1}\right)^{*}$ & 0.927 & 7.322 & 0.021 & 2.344 & 1 \\
Business status $\left(\mathrm{X}_{2}\right)$ & 0.084 & 0.023 & 0.670 & 1.076 & 1 \\
Household size $\left(\mathrm{X}_{3}\right)^{*}$ & 1.292 & 4.676 & 0.024 & 3.423 & 1 \\
Constants & -3.965 & 139.281 & 0.000 & 0.041 & 1 \\
\hline
\end{tabular}

$\chi^{2}$ with $\mathrm{df}=3$ amounted to 9.688

$\chi^{2}$ value with $\mathrm{df}=3$ and the value $\alpha=5$ per cent amounting to 7.815

Note: $\left.{ }^{*}\right)=$ Significant at the level of error $(\alpha) 0.05$

Based on the findings, it turns out each diverse variables influence the consumption pattern of household small businesses. From the result of regression value $\chi^{2}$ statistic amounted to 9.688 , while the value of $\chi^{2}$ value with $\mathrm{df}=3$ and the value $\alpha=5$ per cent amounting to 7.815 , so that the value $\chi^{2}$ statistic $>\chi^{2}$ value. Thus, all variables consist of the household heads' education level, business status and household size simultaneously significant effect on consumption patterns of household small businesses.

The relationship between household heads' education level $\left(X_{1}\right)$ and consumption pattern of household small businesses in urban $(Y)$ is positive. It means that amount of household consumption patterns small businesses in urban affected by household head's education level itself. Table 1 shows that the education variable regression coefficient 0.927 and significance probability of 0.021 . This, 
therefore, means that the influence of education on consumption patterns of household small businesses in urban significantly. The higher a person's education, consumption expenditure will also be higher, thus affecting consumption patterns and positive relationship. By the time a person or family has higher education, the necessities of life more and more (Iyangbe \& Orewa, 2009; Ehirim, 2010, Hasan, 2018).

The relationship between business status $\left(\mathrm{X}_{2}\right)$ and the consumption pattern of household small businesses in urban is positive. It means that households have a side business status tend to consume food more to meet the needs of the food compared to non-food needs. Table 1 shows that the regression coefficient of 0,084 business status variables and probability significance of 0.670 . Thus, it means that the business status influences the consumption pattern of households small businesses in urban is not significant. Status of small businesses, both in the form of the main business and side business, does not have a significant influence on consumption patterns due to meet his needs some small business operators to do other work. The main occupations of the respondents as small business operator are government employees, laborers, and private employees.

The next variable household size shows the relationship between household size $\left(X_{3}\right)$ and consumption patterns of household urban small businesses also generate a positive regression coefficient. That is, more or less the pattern of household consumption of small businesses in urban areas significantly affected by the size of the household. Table 1 shows that the regression coefficient of household size and the probability significance 1.292 at 0.024 . This, therefore, means that the effect of family size on the consumption patterns of poor urban households significantly. The number of dependents is one of the factors that influence household consumption patterns. The number of family members, the consumption patterns increasingly varied for each member of the household may not necessarily have the same tastes. The number of family members related to household income which ultimately will affect the consumption pattern of household (Umeh \&Asogwa, 2012).

The results of the logistic model estimation equation on poor households with an average spending of lower categories logistic regression model is obtained as follows:

$\mathrm{Y}=\operatorname{Ln}\{\mathrm{p} / 1-\mathrm{p}\}=-3.965+0.927 \mathrm{X}_{1}+0,084 \mathrm{X}_{2}+1,292 \mathrm{X}_{3}$

According to the logistic model, obtained estimator $\beta_{\mathrm{o}}=-3.9965$, household heads' education level $\left(\beta_{1}\right)=0.927$, business status $\left(\beta_{2}\right)=0.084$ and household size $\left(\beta_{3}\right)=1.292$ were determined using a maximum inclination estimation method, with the understanding that the observed results or the value of having a maximum inclination.

Furthermore, to determine the proportion of households allocate household spending to meet the needs of the food according to education, business status and household size were analyzed using Odd-Ratio (OR). The research findings indicate the proportion of household heads JSE lower household expenditure allocated to meet the food needs to reach 50 percent or more of the total expenditure is as much as 15.40 percent. Meanwhile, the Odd-value ratio (OR) of the education variable head of the family of the results of the logistic regression of 2,344. That is, the possibility of family heads JSE under which allocates spending on food group consumption by 2,344 times compared with high school-educated household head upwards.

The proportion of households with a side business status of household expenditure allocated to meet the food needs of 50 percent or more of total expenditure is as much as 8.00 percent. Meanwhile, the Odd-value ratio (OR) of the variable business status of the results of a logistic regression of 1.076. That is, the possibility of households that own a small business with a status sideline allocate spend to the consumption of food groups of 50 percent or more is equal to 1,076 times compared with households with main business status.

The proportion of households with a family size of 5 or more people who allocate household spending to meet the food needs of 50 percent or more of total expenditure is as much as 17.33 percent. Meanwhile, the Odd-value ratio (OR) of variable size household of the results of a logistic 
regression of 3.135. That is, the possibility that the size of the family's household 5 or more people who allocate spend to the consumption of food groups of $50 \%$ or more is equal to 3.423 times compared with households with a family size of 1-4 people.

The results of this study have important implications because it shows that education of household head and household size significantly affect household consumption patterns of small businesses, ceteris paribus. Education of household head and household size are the most important predictors of household consumption patterns of small business operators.

Observations of education of household head is associated with the behavior of the household because the head of household is the decision maker in the family. It can generally be attributed that education will shape one's breadth of knowledge and will greatly affect consumer behavior and decision-making. The education level of the household head has an additional effect on personal and household expenses as found by Yueh (2006) and Omori (2010).

Associated with household size, most of the existing research provides insights that affect family size savings and household consumption expenditure, but in the opposite direction (Rehman et al., 2010, 2011). With increasing household size, income diverted from savings and individual savings income ratio consequently lowered. However, due to the presence of a large number of economically active members, there is the possibility of saving the average family-sized over-membered family groups lower. Nevertheless, the majority of empirical findings of research suggests that family size has a negative effect on savings, because of the increased number of family members to lower savings, resulting in a tendency to save dwindling (Bendig et al., 2009). Consumption expenditures, on the other hand, is regarded as a positive function of the size of the household, as proposed by a number of theories of consumption. Each additional family size results in an additional burden on household income levels that lead to the transfer of income on consumption (Dornbusch et al., 2004) and the satisfaction of the needs of daily consumption of each additional family member in an increase in individual consumption earnings ratio. Some researchers argue that in absolute terms, spending a great family consumption may be lower than families with small members, made possible by a large household income levels relatively lower compared to the smaller ones.

\section{Conclusions}

This study found that three variables such as household heads' education level, business status and household size significant effect on household consumption pattern of small businesses simultaneously. However, only household heads' education level and household size were significant effects on household consumption patterns of small businesses partially.

The findings of this study indicate that there are still many heads of household with low education and family size are quite large (over 5 people). In the group of these households even have gained significant revenue, but because education is still relatively low and the number of household members was great too, the idea of allocating expenditure for non food is still relatively low, so the savings and investment for the development of their business are still not optimal yet.

The implication of this research is the provision of capital and empowerment of household small businesses that are in informal sectors needs to be done. With such assistance, the household work done economically small businesses can thrive and benefit. While the empowerment provided can be in the form of an increase in the attitude / mental of entrepreneur, quality of business management, finance and marketing.

\section{Acknowledgments}

We would like to thank the Directorate of Higher Education, Ministry of Research, Technology and Higher Education, the Republic of Indonesia for Reviews their financial support of this research. We thank the Research Institution of Universitas Negeri Makassar (UNM), and to the anonymous reviewers are for excellent comments and suggestions for this paper. 


\section{References}

Acs, Z. \& Mueller, P. (2008). Employment effects of business dynamics: Mice, Gazelles and Elephants. Small Business Economics, 30 (1), 85-100.

Alsos G., Ljunggren, E, and Pettersen L. T. (2003). Farm-based entrepreneurs: what triggers the start up of new business activities? Journal of Small Business and Enterprise Development 10: 435-443.

Alsos, G., and Carter, S. (2006). Multiple business ownership in the norwegian farm sector: resource transfer and performance consequences, Journal of Rural Studies 22(2) 313-322.

Alsos G., Carter, S., and Ljunggren E. (2012). Complexities of portfolio entrepreneurship: the Business household nexus. Presented to the Academy of Management Conference, Boston.

Alsos, G., Carter, S. and Ljunggren, E. (2014a) Kinship and business: how entrepreneurial households facilitate business growth. Entrepreneurship \& Regional Development 26, 1-2: 97-122.

Alsos, G., Ljunggren, E. and Carter, S. (2014b). Entrepreneurial families and households. In F. Welter and T. Baker (Eds.) The Routledge Companion to Entrepreneurship London: Routledge, pp. 165-177.

Ayyagari, M., Beck, T., \&Demirgüç-Kunt, A. (2007). Small and medium enterprises across the globe, Small Business Economics, 29 (4), 415-434.

Ayyagari, M., Demirguc-Kunt, A., \&Maksimovic, V. (2008). How important are financing constraints? the role of finance in the business environment, The World Bank Economic Review, 22 (3), 483516.

Barda, C. \&Sardianou, E. (2010). Analyzing consumers 'activism' in response to rising prices, International Journal of Consumer Studies, 34, 133-139.

Bendig, M., L. Giesbert and S. Steiner. (2009). Savings, credit and insurance: household demand for formal financial services in rural ghana. GIGA WP 94/2009, GIGA-German Institute of Global and Area Studies, Germany.

Carlos M.Jardon,Amandio Dasilva, (2017). Intellectual capital and environmental concern in subsistence, Small Businesses, Management of Environmental Quality: An International Journal, 28(2), pp.214-230.

Carter, S., Mwaura, S., Ram, M., Trehan, K.\& Jones, T. (2015). Barriers to ethnic minority and women's enterprise: existing evidence, policy tensions and unsettled questions. International Small Business Journal, 33,(1), pp. 49-69.

De Massis A., Sharma P. Chua JH, \& Chrisman JJ (2012). Family Business Studies: An Annotated Bibliography. Edward Elgar, Cheltenham Glos, UK.

De Massis A. Frattini F., \&Lichtenthaler U. (2013). Research on technological innovation in family firms: present debates and future directions. Family Business Review, 26 (1), 10-31.

De Massis A., F. Chirico, Kotlar J., \& Naldi L. (2014a). The temporal evolution of proactiveness in family firms: the horizontal s-curve hypothesis. Family Business Review, 27 (1), 35-50.

De Massis, A., Kotlar, J. Chua, JH, \& Chrisman, JJ (2014b). Ability and willingness as sufficiency conditions for particularistic family oriented behavior: implications for theory and empirical studies. Journal of Small Business Management, 52, 344-364.

De Massis A., Di Minin A., \&Frattini F. (2015). Family driven innovation: resolving the paradox in family firms. California Management Review, 58 (1), 5-19.

De Massis, A., Kotlar, J., Frattini, F., Chrisman, J., \&Nordqvist, M. (2016). Family Governance at Work: Organizing for New Product Development in Family SMEs. Family Business Review, 29, 189213.

Dornbusch, R., S. Fischer and R. Startz. (2004). Macroeconomics. 9th Edt., The McGraw-Hill Company, New Delhi.

Ehirim, N.C (2010). Determinants of consumers' preference for safe chicken consumption in imo state, nigeria. Science pub journal 2 (12), 2010, 42-50.

Francisco, H., Ferreira., G., Fruttero, A. Leile, P. \&Lucchetti, R. (2013). Rising food prices and household welfare: evidence from brazil in 2008, the Journal of Agricultural Economics, 64, 151176. 
Garcia, T. \& Grande, I. (2010). Determinants of food expenditure patterns among older consumers. The Spanish case, Appetite, 24, 62-70.

Gheblawi, M., \&Sherif, S. (2007). Determination of factors affecting expenditures on three major food groups in al-Ain, the united arab emirates (UAE). Emirates Journal of Food and Agriculture, 19 (2), 15-23.

Gonzales, E. (2013). SMEs in relation to poverty, employment, and productivity: setting the way forward. Literature Review Paper, Internal Report. Washington, DC: Inter-American Development Bank.

Haltiwanger, J., Jarmin, R., \& Miranda, J. (2010). Who creates jobs? small vs. large vs. young. National Bureau of Economic Research, NBER Working Papers, 16300.

Hasan, M. (2013). Karakteristik tenaga kerja industri kecil. Jurnal Ekonomi Pembangunan danPertanian 2(1) Februari 2013 ISSN 2252-4878. Makassar: Program Studi Ekonomi Pembangunan FE UNM.

Hasan, M. (2014). Produktivitas dan elastisitas kesempatan kerja sektor industri. Jurnal Economix 2(1) Desember 2014 ISSN 2302-6286. Makassar: Fakultas Ekonomi UNM.

Hasan, M. 2018. Pembinaan Ekonomi Kreatif dalam Perspektif Pendidikan Ekonomi. Jurnal Ekonomi dan Pendidikan (JEKPEND) 1( 1), Januari 2018 p-ISSN: 2614-2139; e-ISSN: 2614-1973.

Hasyim, H., dan Hasan, M. (2017). Strategi Pemberdayaan dan Keunggulan Bersaing Industri Kecil, Prosiding Seminar Nasional Dies Nataliske 56 Universitas Negeri Makassar. Makassar: Penerbit UNM.

Hurst, E. \& Pugsley, BW (2011). What Do Small Businesses Do? National Bureau of Economic Research Working Paper Series, 17041.

Iyangbe CO and SI Orewa. (2009). Determinants of daily protein intake among rural and low income urban households in nigeria, The American-Eurasian Journal of Scientific Research 4 (4), 2009, 290301.

Jacobson, D., Mavrikiou, P. \& Minas, C. (2010). Household size, income and expenditure on food: the case of cyprus, The Journal of Socio-Economics, 39, 319-328.

Karedza, G. Sikwila, M. Mpofu, T. And Makurumidze, S. (2014). An analysis of the obstacles to the success of SMEs in chinhoyi, zimbabwe. European Journal of Business and Management (Online), 6(6) pp. 40 (Online) ISSN 2222-1905 (Paper) ISSN 2222- 2839.

Khavul, S, GD Bruton and E Wood. (2009). Informal family business in africa. Entrepreneurship: Theory and Practice, 33 (6), 1219-38.

Klapper, L., Lewin, A., \& Quesada, J. (2009). The Impact of the business environment on the business creation process, Policy Research Working Paper, 4937, The World Bank.

Liu, M., Kasteridis, P. \& Yen, S. (2013). Breakfast, lunch, and dinner expenditures away from home in the united states, the Food Policy, 38, 156-165.

Mazzucato, M. (2013). The entrepreneurial state: debunking public vs. private Sector myths (1st ed.). United States of America: Anthem Press.

Miliaras, C. (2012). Creating jobs that reduce poverty: a research agenda on developing country gazelles. RTI Press Publications, OP-0011-1211. Research Triangle Park, NC: RTI Press.

Neulinger, A. \& Simon, J. (2011). Food Consumption patterns and healthy eating across the household life cycle in hungary, International Journal of Consumer Studies, 35, 538-544.

Omori, M. (2010). Household expenditures on children, 2007-2008. Monthly Labor Review, 133 (9): 316.

Rehman, H., M. Z.Faridi and F. Bashir. (2010). Households saving behavior in pakistan: a case of multan district. Sir. J. Soc. Sci., 30: 17-29.

Rehman, H., F. Bashir and M. Z.Faridi. (2011). Saving behavior among different income groups in pakistan: a micro study. Int. Humanities J. Soc. Sci., 1: 268-277.

Stangler, D. \&Litan, R. (2009). Where will the jobs come from? Kauffman Foundation Research Series: Formation and Economic Growth Firms Paper, 01.

Tekguc, H. (2012). Separability between own food consumption production and consumption in turkey, Rev. Econ Household, 12, 423-439. 
Umeh, J. C. and Asogwa, C. B. (2012). Determinants of farm household food expenditure: implications for food security in rural nigeria. International Conference on Ecology, Agriculture and Chemical Engineering (ICEACS'2012) December 18-19, 2012 Phuket (Thailand)

Viswanathan, M, R,. Echambadi, S, V., and Sridharan,S (2014). Subsistence entrepreneurship, value creation and community exchange systems: a social capital explanation. Journal of Macromarketing, 34 (2), 213-26.

Vitaliano, D. (2010). Engel curves and the unitary theory of the household, International Journal of Consumer Studies, 34, 69-72.

Wales, W. J., Patel, P. C., Parida, V. and Kreiser, P. M. (2013). Nonlinear effects of entrepreneurial orientation on small firm performance: the moderating role of resource orchestration capabilities. Strategic Entrepreneurship Journal 7 (2): 93-121.

Welter, F. (2011). Contextualizing Entrepreneurship - Conceptual Challenges and Ways Forward. Entrepreneurship, Theory and Practice, 35, 165-184.

Yueh, L. (2006). Parental Investment in Children's Human Capital in Urban China, Applied Economics, 38: 2089-111.

Zahra, S. A. (2006). New Venture Strategy: Transforming Caterpillars into Butterflies. In: Parker SC (ed). The Life Cycle of the Entrepreneurial Venture. Boston, MA: Kluwer.

Zahra, S. A. (2007). Contextualizing theory building in entrepreneurship research. Journal of Business Venturing 22 (3): 443-452. 